been subjected had a very prejudicial effect upon his health. He declared he should have no peace until his son and the keeper were committed for contempt, and begged me to go at once to Baron Cleasby. This I did, but, being Sunday, nothing effectual could be done, and upon returning to Huntingdon-street the solicitor, after much trouble, discovered the General was dead. I do not suppose Dr. Tuke bas purposely misstated the facts, but he would lead the public to believe that upon my representation the Commissioners instituted an inquiry. I annex a copy of their last letter to me in reply to my request, after the General's death, that an inquiry might be instituted. Dr. Tuke says the imprisonment lasted twelve days. The number was thirty-two. $\mathrm{He}$ says that upon application "Judge's orders were freely made to give me access to the patient." The above facts speak for themselves. And he adds: "The action by the learned Judge proves how much importance be attached to the question, and the promptitude with which he would have acted if he had found it necessary;" whereas, as soon as the various obstacles thrown in the way were removed, the Judge did act, but, backed by Dr. Tuke's certificate, the son actually set the Judge at defiance. I have no doubt Dr. Tuke was imposed upon, but what would he have said if the General bad made a will in favour of the persons with whom he had resided so many years, and then, in conse. quence of kindness shown him by his sons during his illness, he had altered it in their favour? Would Dr. Tuke have then said be was acting under "undue influence and suffering from senile imbecility?" I think he will, now that he knows the truth, regret that he signed the certificate so readily.

There are, of course, numerous other facts, but I have trespassed too much already upon your space. I will only add that $I$ have placed all the circumstances before the Home Secretary with a view to an alteration being made in the existing law, under which, I have no hesitation in saying, any English man or woman can be locked up in his or her own house without the possibility of seeing anyone but those who have taken the proceedings or who have been selected to carry them out. I trust I have said sufficient to induce you to lend me your valuable aid to ensure an altera. tion in the law. I have no pecuniary interest in the case, and am acting solely as the friend and executor of the late General Reece.-I am, Sir, your obedient servant,

Parliament-street, London, August 25th, 1875.

S. P. Low.

\section{THE WEBB TESTIMONIAL FUND.}

To the Editor of THE LANCET.

SiR,-Captain Webb is the son of a medical man in this neighbourhood, who is highly respected for his remarkable integrity of character and strictly upright and honest dealing in his profession; his grandfather and uncle were also surgeons of high standing, practising extensively some years ago near Wellington, Salop, and his eldest brother has succeeded his father, who from a long and laborious practice is too much enfeebled to render any assistance.

I should be much pleased to see a fund raised by medical men, to acknowledge the unprecedented feat and undaunted bravery of the son of a professional brother, who has had a family of fourteen children, twelve of whom are living.

I enclose a P.O.O. for two guineas.

$$
\text { I am, Sir, yours truly, }
$$

Edward G. Bartham, F.R.C.S.

Brosley, Salop, August 30th, 1875 .

** We have much pleasure in inserting the above letter, and shall be most happy to receive subscriptions for the furtherance of this fund. Amounts already received:Dr. J. G. Wakley, £2 2s.; Mr. John Tweedy, \&2 2s.; Mr. E. G. Bartlam, £2 2s.; Mr. S. Potter, \&2 $2 s$.

\section{IRELAND.}

(From our own Correspondent.)

THE prospect of a good harvest is very general throughout this island, notwithstanding the occurrence of heavy rain in some parts of the country, the effects of which are considered injurious according to the local reports.
Foot and mouth disease has occurred in some parts of Ireland; it is boped, however, that, the extent of its ravages is not very considerable.

The loss of nearly fifty thousand sheep in Ireland last year by dogs certainly demands the attentive consideration of the authorities. Doubling the dog tax and the im mediate destruction of the many mongrels, and other apparently ownerless dogs now at large in this island, appear more than ever necessary at the present time. We look on the preservation of our food supplies as a medical matter, concerning so intimately as it does the public health.

Apropos of the enlargement and rebuilding of Coombe Hospital, now rapidly approaching completion, thanks to the very important aid of Sir Arthur Gainness, Bart., we nuay mention that a grateful remembrance of the present Baronet's father, to whose munificence Dublin owes the restoring of St. Patrick's cathedral, in the shape of a very interesting statue by the late Mr. Foley, has just been placed on its handsome pedestal within the railing which surrounds the cathedral in Guinness-street, on the south side of the nave of the cathedral. We have just had the pleasure of inspecting this very admirable work of art, which is a faithful likeness, and which is peculiarly interesting as being, it is said, the last of the eminent artist's works which received his final touches.

At the last meeting of the Dublin Sanitary Association, a resolution of condolence with the family of the late Dr. D. T. T. Maunsell was unanimously adopted. A resolution was also unanimously adopted by the same body, expressive of the desirability for prompt action, by the local Sanitary Authorities of Dublin, under the Artisans and Labourers' Dwellings Improvement Act of 1875 , in a city where those classes suffer, as they at present so much do, from the want of suitable dwellings.

Dublin, September 1st, 1875 .

\section{(10bituarn.}

\section{JAMES NANCE, F.R.C.S. ENG.}

Mr. Nance, the only surviving son of the Rev. John Nance, D.D., rector of Hope and Old Romney, Kent, was born on 20th May, 1818. He was articled to Curtis and Son, of Dorking, in 1835; afterwards studied at University College; became M.R.C.S. Eng. and L S.A. Lond. in 1840, and F.R.C.S.E. in 1864. He practised at Eccleshall, Staffordshire, for upwards of thirty years, and died there, on May 15th, from (1) coma and (2) irritative fever, after a fortnight's illness, aged fifty-six.

His estimable and honourable conduct gained him universal respect, while his generosity of character and kindness of heart made him many friends. His medical skill, care, and attention, were bestowed as freely on the poor as on the rich, and even more abundantly, very often in cases in which no remuneration was ever asked for or thought of.

His funeral took place at Eccleshall on May 20th, and was attended by a large number of the inhabitants of Eccleshall, together with representatives from the various clubs of which he was the medical officer, as well as by numerous friends, assembled from far and wide to show public testimony to his worth. His name will ever be treasured in the memory of his friends and in the gratitude of the poor.

\section{JOHN THOMAS MERCER, M.B.}

A roung man has recently passed away, immolated at the shrine of his profession by diphtheria. Gentle, kind, and unobtrusive, he never made an enemy. To the poor his life was one continued benefaction. When they heard of his death they stood aghast in tearful groups of four or five, and each one had some past benefit to recount. His every neighbour felt that he had lost a friend, and his convalescent patients went to bed again, so great was the shock to them. It is not a little thing to make a mark like this at the age of thirty-six; yet it is a grateful tributo 